tained. This family approach would help in identifying risk factors for a young child to future diseases like diabetes and hypertension and lifestyle modification could begin even at an early age. He said if we were proactive we could transform policy to a reality with the help of IT.

K. Kasturirangan (Department of Space) spoke of 'Education and Health Care: Bridging the Access Divide' and the use of space technology as a tool for bridging this divide. He said the Indian innovation of exploiting the vantage point of space for social upliftment, empowerment of the rural population, developmental communication, training the trainers, among many others draws no parallel. Kasturirangan said that space offers the plausibility of transferring patient records, medical images and laboratory results through reliable voice and data links enabled by VSAT technology. This would ensure linking the islands of medical skill with the vast mainland of needs. Successful pilot projects have been undertaken already in some states such as Tamil Nadu, Karnataka, West Bengal and Tripura. The health care net, he said, would be expanded to Leh, Andaman and the North-East. In an experiment in Jhabua, Madhya Pradesh - a mainly tribal belt - programmes were beamed on health, watershed development and role of women, etc. to about 150 hamlets. The insights into decentralized health care for the 'peoples sector in health and medical care'. Health in the 'Peoples Health Sector' is primarily a function of the individual, family and the local community. An Indian Council for Social Science Research (ICSSR)/Indian Council for Medical Research (ICMR) Report (1981) titled 'Health for All-An alternative strategy' (prepared under the chairmanship of V. Ramalingaswami) provided for a 'more holistic concept of both health as well as medical care', felt Antia. Medical aspects were graded either as those requiring social skills or technology. The report stated that $70 \%$ of all health care could be undertaken by e.g. a female village health functionary covering 200 people. Another $15 \%$ of health care problems could be attended by local female paramedical workers (Sahyoginis) trained for two years and each could help about 5000 people. At the taluka/block level, $95 \%$ of all health could be treated with the help of a 40-bed people's hospital having good infrastructure that could cater to 100,000 population. And the same hospital, together with a "dharmashala' could provide medical (including surgical) facilities that would further extend the size of the facilities. Only 5\% would require super-speciality skills and facilities at the district or city level.

According to Antia, despite a national etc. It is based mostly on the western model with only $4 \%$ of its budget provided to the Indian Systems of Medicine and Homeopathy, added Antia. On the other hand, he felt the private sector which now accounts for three quarters of the national health expenditure is almost entirely curative and hence profit-oriented. Even the poorest are now expending $20 \%$ of their meagre household expenditure on such services under duress of pain and suffering, and is only next to dowry as the cause of rural indebtedness. This is the result of the failure of the public sector, he added.

Antia cited several advantages of a community's own health care system which are closely interrelated with the development of Panchayati Raj. He added, as it may take over a decade for the Panchayati Raj to operate effectively on a countrywide scale, various methods for implementing the broad strategies of the Community Health Care System will have to be evolved in the interim period depending on local socio-economic, cultural, epidemiological and geographic conditions.

With the Health Policy of the Government of India in the making, it is hoped that some of these issues could be seriously considered and proper steps taken on a war footing for their implementation. Health care could only then become

\title{
Whither electric vehicles?
}

Electricity is the natural medium for the application of motive power. Its supply is unlimited. It is everywhere. It is to movement what the sun is to growth.

- Western Electrician, January 1889

In the late 1890 s, at the dawn of the automobile era, steam, gasoline and electric vehicles all competed to become the dominant automobile technology. By the early 1900s, the battle was over and Internal Combustion Engine Vehicles
(ICEVs) were poised to become the prime movers of the twentieth century.

At present, about 60 million ICEVs are manufactured every year worldwide and it is projected that there would be about one billion ICEVs on the earth's roads by 2002 , i.e. one for every seven people. This upsurge in the use of ICEVs is causing considerable pollution problems in our urban conurbations. In response to the growing concerns over the urban air quality, the state of California enacted in 1994, a legislation requiring that by $1998,2 \%$ of cars offered for sale be zero-emission, increasing to $5 \%$ by 2000 and ultimately $10 \%$ by 2003 . These deadlines however have been amended, largely because of the failure of batterypowered vehicles, which were originally seen as a solution, to perform at a level approaching that of the existing ICEVs. However, pure battery-powered vehicles are no longer regarded as an acceptable alternative to ICEVs, except possibly as Neighbourhood Electric Vehicles (NEVs) which are designed to provide low-speed 
transportation in restricted areas such as university campuses, hospitals, airports, theme parks, industrial parks, holiday resorts, residential complexes and city centres.

The above situation does not imply that there are no legitimate uses of pure battery-powered electric cars today as fleet vehicles, as community cars and as second cars for families that already own a gasoline automobile for long-distance travel. One solution to this enigma might be to take the pure battery-powered electric cars out of the development laboratories and put them in the hands of the real drivers. Some will find these vehicles inadequate, but many others may not. With this proposition in mind, Saturn, in partnership with General Motors Advanced Technology Vehicles, now offers GEN II EV1 to consumers through a lease-only programme. Select Saturn retail facilities in California and Arizona distribute and service EV1. Saturn believes that this is the best way to ensure total customer enthusiasm for the early customers in their vehicle. Leasing will provide the customers with a known, consistent cost of ownership. Saturn covers all routine maintenance and service under the terms of 3-year/36000-miles new-vehicle limited warranty. This includes everything from batteries to tyres. Saturn also provides a 24-hour roadside assistance programme, to make every aspect of EV1 lease trouble-free.

While the fate of pure battery-powered electric cars hangs in limbo, the last five years has seen a dramatic development in fuel cells which have advanced to the point where manufacturers believe that the technology is commercially viable and capable of delivering sufficient energy for running the cars. Among various types of fuel cells, the low-operating temperature and rapid start-up characteristics, together with its robust solid-state construction give the Polymer Electrolyte Fuel Cells (PEFCs) a clear advantage for application in cars. The energy conversion efficiency of PEFCs is much higher than both Otto and Diesel versions of internal combustion engines.

The preferred fuel for PEFCs is hydrogen. Various strategies for providing hydrogen to PEFCs are presently being evaluated. Broadly speaking, these strategies could be divided into two categories: (a) to generate hydrogen on-board and on-demand from liquid hydrocarbon or methanol, and (b) to directly fuel hydrogen from a storage tank containing compressed/liquid hydrogen. Experts believe that for Fuel Cell Vehicles (FCVs) with an on-board fuel processor, it would be difficult to exceed the performance of the future ICEVs in terms of emission, efficiency, drivability, maintenance and first cost. By contrast, if the FCVs are powered by a directlyfuelled fuel cell, then there is every prospect that the performance of such vehicles will exceed that of the ICEVs, but not the first cost. However, given the recent rate of progress in PEFC technology, we expect a significant reduction in the cost of directly-fuelled fuel cells.

For direct-hydrogen FCVs, the main task is to develop a cost-effective, reliable and safe method of storing sufficient hydrogen on-board. Particularly, with buses, where there is more room for storage of hydrogen as a compressed gas, there are good prospects that commercial fuel-cell powered versions will be on the roads within 2 to 3 years. Such vehicles are centrally refuelled and therefore hydrogen-distribution infrastructure is not a critical issue.

Some car manufacturers undertaking the development of FCVs are Daimler-Chrysler who have a joint venture with Ballard, EXCELLSIS, Ecostar and Ford, General Motors with Opel, Honda, Mazda, Nissan, Renault, Toyota, Volkswagon and ZeTech. While some of these manufacturers are attempting to develop pure fuel-cell powered FCVs, others are attempting to develop vehicles either with a fuel cellbattery hybrid system or with a fuel cellsupercapacitor hybrid system. The problems that remain to be tackled are reduction in cost, weight and volume of fuel-cell systems, further improvements in driving dynamics, durability and reliability, development of cost-effective production technologies and installation of refuelling infrastructure for methanol and hydrogen. Although each of these problems represents a big challenge, FCV developers look committed to commercialize FCVs, and some of them as early as the middle of this decade.

A. K. Shukla, Solid State and Structural Chemistry Unit, Indian Institute of Science, Bangalore 560012 , India (e-mail: shukla@sscu.iisc.ernet.in). 